第七十七巻第一号 人 類 学 杂隹 誌 昭和四十四年二月

\title{
Principal Pattern of the Dynamic Change in the Force of Human Foot during Walking*
}

\author{
Banri Endo, ${ }^{1)}$ Akira TAKAhashi, ${ }^{2)}$ Mamoru Tomita ${ }^{1)}$ \\ and Tasuku Kimura ${ }^{1)}$
}

\section{INTRODUCTION}

The bipedal walking has been said to be one of the most important human characteristics and attracted many investigators. The subject has been studied in various ways: for instance, postural analysis by means of photograph, analysis of external work by means of accerelometer, analysis of muscle action by means of electromyograph, measurement of energy consumption. However, not many investigations have been made to reveal the exact condition of three dimensional forces of human foot acting on the level floor from the dynamic point of view. SCHENK (1937) examined the vertical force dynamically, and RAuHut (1937) also showed the antero-posterior force of the foot. Elftiman (1939) built a force plate and observed three force components. SAunders et al. (1953) designed a four columns force plate with strain gauges and presented the vertical and sagittal forces. Goroh (1959) made a force plate with differential transformers and analysed dynamic three dimensional forces. Recently many short reports about this problem have been published (HAYASHIBARA et al. 1965, Contini et al. 1965, Rydell 1966, CAvagna and Margaria 1966, IWAI et al. 1967).

The present authors intend to make a series of studies to clarify the mechanical features of the human walking, which may provide data for the further studies on the human locomotion system. The present study concerns with the principal pattern of the dynamic change in the force of human foot acting upon the level floor during a cycle of walking motion.

\section{MATERIALS AND METHODS}

The subjects examined consist of 10 normal adult Japanese: five males and

\footnotetext{
* A part of this study was presented at the 20th Joint Meeting of the Anthropological Society of Nippon and the Japanese Society of Ethnology held at Sendai in October, 1965. 


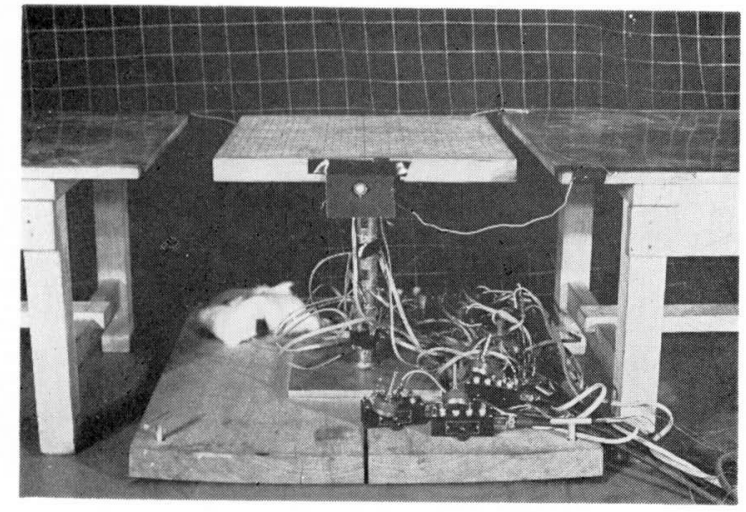

Fig. 1 The force plate.

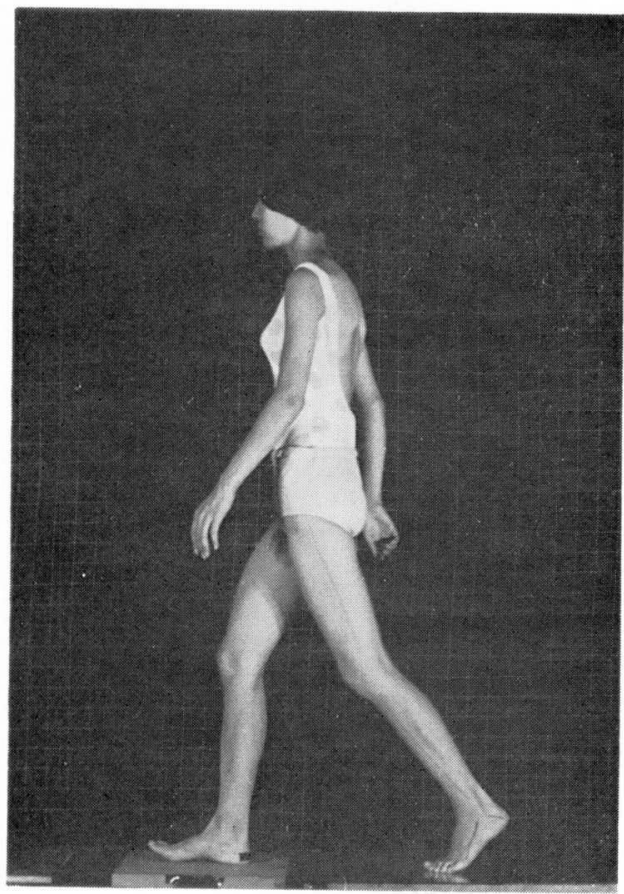

Fig. 3 A subject in walking on the platform.

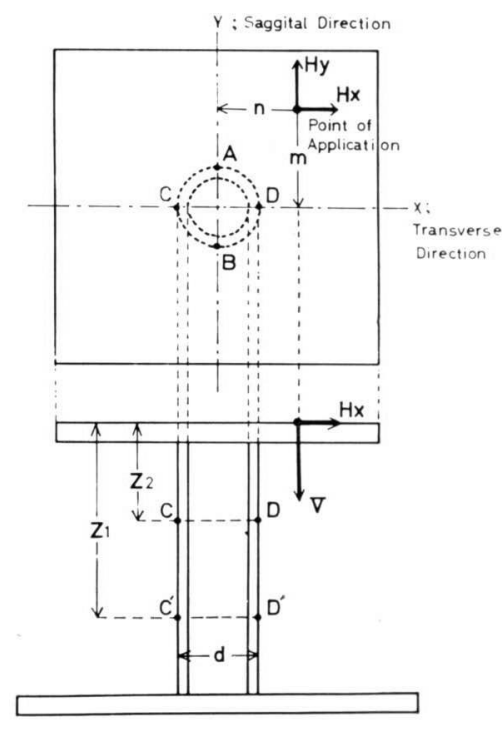

$\sigma_{\mathrm{A}}=-\frac{\mathrm{V}}{\mathrm{A}}-\frac{\mathrm{d}}{2 \mathrm{I}_{\mathrm{y}}}\left(\mathrm{mV}+\mathrm{Z}_{1} \mathrm{H}_{\mathrm{y}}\right)$

$\sigma_{\mathrm{B}}=-\frac{\mathrm{V}}{\mathrm{A}}+\frac{\mathrm{d}}{2 \mathrm{I}_{\mathrm{y}}}\left(\mathrm{mV}+\mathrm{Z}_{1} \mathrm{H}_{\mathrm{y}}\right)$

$\sigma_{\mathrm{C}}=-\frac{\mathrm{V}}{\mathrm{A}}+\frac{\mathrm{d}}{2 \mathrm{I}_{\mathrm{X}}}\left(\mathrm{nV}+\mathrm{Z}_{1} \mathrm{H}_{\mathrm{X}}\right)$

$\sigma_{\mathrm{D}}=-\frac{\mathrm{V}}{\mathrm{A}}-\frac{\mathrm{d}}{2 \mathrm{I}_{\mathrm{x}}}\left(\mathrm{nV}+Z_{1} \mathrm{H}_{\mathrm{X}}\right)$

$\mathrm{V}=-\mathrm{A} \cdot \frac{\sigma_{\mathrm{A}}+\sigma_{\mathrm{B}}}{2}$

$\mathrm{H}_{\mathrm{y}}=\frac{\mathrm{I}_{\mathrm{y}}}{\mathrm{d}\left(\mathrm{Z}_{2}-\mathrm{Z}_{1}\right)} \cdot \frac{\sigma_{\mathbf{A}}-\sigma_{\mathbf{A}^{\prime}}}{2}$

$\mathrm{H}_{\mathrm{x}}=\frac{\mathrm{I}_{\mathrm{x}}}{\mathrm{d}\left(\mathrm{Z}_{2}-\mathrm{Z}_{1}\right)} \cdot \frac{\sigma_{\mathrm{C}}-\sigma_{\mathrm{C}^{\prime}}}{2}$

$\mathrm{m}=\frac{1}{\mathrm{~V}}\left\{\left(\sigma_{\mathrm{B}}-\sigma_{\mathbf{A}}\right) \cdot \frac{\mathrm{I}_{\mathrm{y}}}{\mathrm{d}}-\mathrm{Z}_{1} \mathrm{H}_{\mathrm{y}}\right\}$

$\mathrm{n}=\frac{1}{\mathrm{~V}}\left\{\left(\sigma_{\mathrm{C}}-\sigma_{\mathrm{D}}\right) \cdot \frac{\mathrm{I}_{\mathrm{x}}}{\mathrm{d}}-\mathrm{Z}_{1} \mathrm{H}_{\mathrm{x}}\right\}$

Fig. 2 Diagram of the force plate. $\sigma_{\mathrm{A}} \cdots \sigma_{\mathrm{D}^{\prime}}$ : Stress in vertical direction at point $\mathrm{A} \cdots \mathrm{D}^{\prime}$; $\mathrm{A}$ : Area of the leg; $I_{x}, I_{y}$ : Moment of inertia of area of the leg in transverse and sagittal direction.

five females. Before any experiment was made, measurements were taken of each individual on items shown in Table 1 . The force of the foot changing dynamically during walking was measured by a dynamometer specially devised for the present experiment (Fig. 1). The dynamometer consists of a onelegged platform with electric wire strain gauges attached to the iron leg. An 
Principal Pattern of the Dynamic Change in the Force of Human Foot during Walking

Table 1 The Somatometrical measurements of subjects.

\begin{tabular}{l|l|l|l|l|l|l|l|r}
\hline subject & $\begin{array}{r}\text { age } \\
\text { sex }\end{array}$ & $\begin{array}{c}\text { body } \\
\text { weight }\end{array}$ & stature & $\begin{array}{c}\text { lower limb } \\
\text { length }\end{array}$ & $\begin{array}{c}\text { thigh } \\
\text { length }\end{array}$ & $\begin{array}{c}\text { leg } \\
\text { length }\end{array}$ & $\begin{array}{c}\text { foot } \\
\text { length }\end{array}$ & $\begin{array}{l}\text { foot } \\
\text { breadth }\end{array}$ \\
\hline M. T. & 28 male & $58.0^{\mathrm{kg}}$ & $161.6^{\mathrm{cm}}$ & $82.5^{\mathrm{cm}}$ & $40.5^{\mathrm{cm}}$ & $35.7^{\mathrm{cm}}$ & $23.0^{\mathrm{cm}}$ & $10.0^{\mathrm{cm}}$ \\
S. I. & 22 " & 57.5 & 170.4 & 86.7 & 43.7 & 36.2 & 25.3 & 10.0 \\
S. K. & 23 " & 51.5 & 159.0 & 81.3 & 40.1 & 35.9 & 23.0 & 9.4 \\
Y. F. & 30 " & 55.5 & 158.0 & 78.9 & 37.9 & 35.0 & 24.0 & 10.0 \\
T. K. & 24 " & 52.0 & 158.6 & 81.2 & 41.3 & 33.6 & 23.5 & 9.6 \\
K. T. & 22 female & 45.5 & 163.5 & 87.1 & 46.1 & 35.1 & 22.4 & 9.1 \\
I. Y. & 21 " & 44.0 & 159.9 & 79.8 & 43.0 & 30.9 & 23.0 & 9.2 \\
J. I. & 23 " & 50.0 & 158.0 & 82.1 & 43.1 & 31.7 & 23.1 & 8.6 \\
K. K. & 17 " & 57.0 & 157.5 & 83.4 & 44.5 & 32.4 & 23.8 & 8.8 \\
H. F. & 17 " & 46.5 & 156.0 & 80.2 & 39.0 & 35.3 & 22.3 & 8.5 \\
\hline
\end{tabular}

arbitrary force acting on the platform can be analysed into three dimensional components (vertical; sagittal; transverse) and the point of application as illustrated in Fig. 2. The strains, which correspond to the above components respectively were measured by the specially arranged gauges, recorded by an

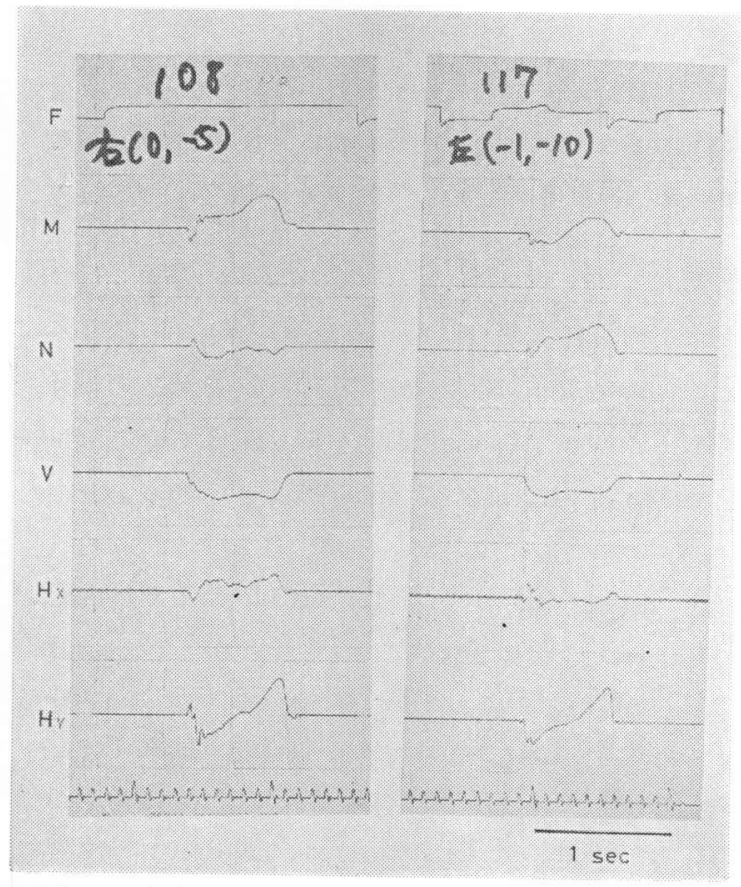

Fig. 4 The forces of the right and left foot. Subject: K. K.; F : Right heel contact period; $\mathrm{M}, \mathrm{N}$ : Data concerned with the point of application; V: Datum of the vertical component; $\mathrm{H}_{y}$ : Datum of the sagittal component; $\mathrm{H}_{\mathrm{x}}$ : Datum of the transverse component. ink-writing oscillograph (San'ei IR-102)and then converted into the forces. The accuracy of the dynamometer can be considered as sufficient to obtain the principal change of the force of foot in walking. The maximum absolute errors in usual measurements are $5 \mathrm{~kg}$ in the vertical force at the center of the force plate; $0.3 \mathrm{~kg}$ in the sagittal force; $0.4 \mathrm{~kg}$ in the transverse force; $0.5 \mathrm{~cm}$ at the point of application in sagittal direction; $0.7 \mathrm{~cm}$ in the transverse direction. As to the measurements of the vertical force and the point of application, the precision of this force plate was not completely sufficient. When a force acts on around the center of the platform, however, these measurements are reliable. This dynamometer has an imperfection that the platform 
vibrates for a while in case of percussion.

The subjects were requested to walk with bare foot in one of the three kinds of speed(slow, natural or quick) about seven steps on a pathway of wooden board, at a certain place where the dynamometer was set (see Fig. 3). The fourth or fifth step was used for the analysis of the force of foot. The speed

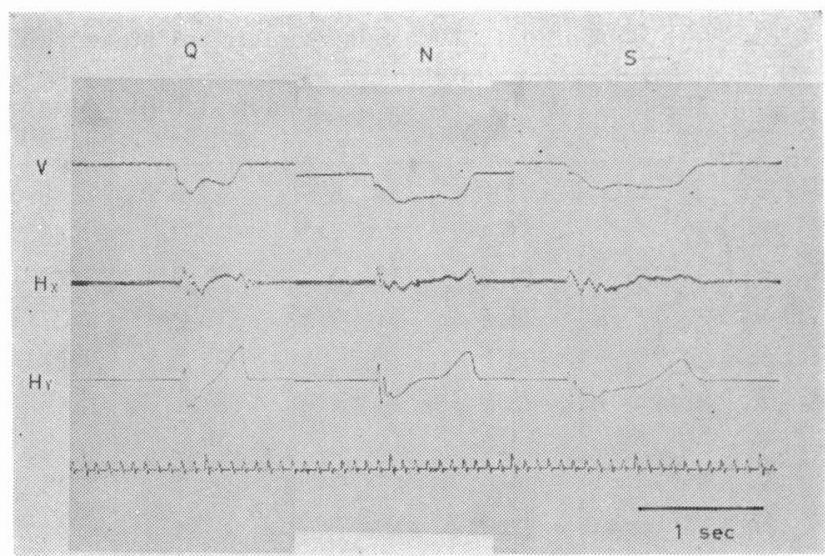

Fig. 5 The variation of components according to the velocity change.

Subject: T. K.; S: Slow; N: Natural; Q: Quick. of walk was calculated from the data obtained by recording the stride duration by means of a contact switch attached at the heel and by measuring the stride length marked on the floor during walk.

The postural change of the subject in walking was recorded by means of the $16 \mathrm{~mm}$ cine-camera with a speed of 32 frames per second. On the lower limb of the subject, lines were drawn along their longitudinal axes in order to measure the angles formed by the thigh, calf and foot on the cinematograph.

\section{RESULTS}

The numerical values of the components of the force of the foot in the sagittal, transverse and vertical directions varied to some degree from individual to individual and according to the way of walking within the same individual. But the patterns of the principal change of the above components were fairly uniform in all the subjects.

Fig. 4 and 5 show exemplary cases of the direct record drawn by ink-writing oscillograph. As shown in Fig. 4, no marked differences were found between the force of the right foot and that of the left foot. The peak of the magnitude of the components varied to some extent in accordance with the walking speed as seen in Fig. 5. In general, the faster the speed, the more distinct the peak. But in the transverse component, no marked difference could be seen. The fundamental changes in the components and the point of application of the foot-force seemed to be little influenced by the walking speed. The relationship between some numerical values of components and percentages of the stance phase are shown in Table 2 .

The principal changes in the sagittal, transverse and vertical components 
Principal Pattern of the Dynamic Change in the Force of Human Foot during Walking 5

Table 2 The magnitude and duration of components.

Ten subjects, Righs foot. Mean weight: $52 \mathrm{~kg}$; Mean stance duration: $0.71 \mathrm{sec}$; Mean velocity: $101 \mathrm{~cm} / \mathrm{sec}$.

\begin{tabular}{|c|c|c|c|c|c|c|c|c|c|c|}
\hline & \multicolumn{4}{|c|}{ V. Component } & \multicolumn{3}{|c|}{ S. Component } & \multicolumn{3}{|c|}{ T. Component } \\
\hline & notch & $\begin{array}{l}1 \text { st } \\
\text { max. }\end{array}$ & $\min$. & $\begin{array}{l}2 \text { 2nd } \\
\max .\end{array}$ & $\begin{array}{l}\text { fore } \\
\text { max. }\end{array}$ & $\mathrm{be}$ & $\begin{array}{l}\mathrm{ck} \\
\max .\end{array}$ & $\begin{array}{c}\text { 1st med. } \\
\text { max. }\end{array}$ & $\begin{array}{l}\text { Ist. } \\
\text { max. }\end{array}$ & $\begin{array}{c}\text { 2nd med. } \\
\text { max. }\end{array}$ \\
\hline Force in $\mathrm{kg}$. & 32 & 62 & 40 & 54 & 7 & 0 & 8 & 3 & 3 & 1 \\
\hline $\begin{array}{l}\% \text { of stance } \\
\text { phase }\end{array}$ & 6 & 23 & 55 & 74 & 15 & 55 & 88 & 7 & - & 94 \\
\hline
\end{tabular}

of the force of foot, and the changes in the directions of the force vector as well as the shift of its point of application during a stance phase in a cycle of natural walking in an exemplary case are illustrated in Fig. 6 along with the postural change of the subject. The five cases of three force components of this subject are shown in Fig. 7. The force components of ten subjects are illustrated in Fig. 8. The outline of the changes are as follows:

Sagittal component At first the component has a forward sense and increases its magnitude rapidly to form a relatively sharp peak around $15 \%$ of the duration of the stance phase. Then it descends forming a relatively straight line and in a easy slope to the zero line. Around the zero line there appears sometimes a small peak. The curve cuts the zero line at about $55 \%$ of the duration. Changing its sense to backward, it increases its magnitude in a straight line until it reaches around $90 \%$ of the duration where it forms a fairly sharp peak. It diminishes towards zero at last in a steep slope. The component in the forward sense means decelerating the forward motion of the body with the heel, whereas the component in the backward sense indicates the acceleration of motion with the ball and toe. The magnitude of the backward peak is slightly higher than that of the forward.

Transverse component The component has, at first, the medial sense and forms a sharp peak at a very early stage, i. e. about $5 \%$ of the duration of the stance phase. Soon after that its sense becomes lateral, and its magnitude forms an easy convex curve. Then the component diminishes gradually and disappears. In some cases it shifts to medial side again before the disappearance. Magnitudes of the peaks are very small.

Vertical component The component has downward sense and its magnitude increases forming a fairly steep line to form a peak around $25 \%$ of the duration of the stance phase. A notch often exists in the steep line before the peak. The curve descends to make a shallow trough, then it again forms a peak around $75 \%$ from the beginning. It disappears at last in a steep slope. The time of the two peaks coincides with the contacting moment of the heel and that of the ball with the floor, respectively. The peaks and 
6

trough become more distinct when the walking speed gets faster. Magnitudes of two peaks are more than the body weight. The magnitude of the first peak is higher than that of the second one. Magnitude of the trough between two peaks is less than the body weight.

Vector of the force The direction of the vector projected on the sagittal elevation (sagittal plane) is inclined about 10 degrees forward from vertical line soon after the heel has touched. It comes near vertical, then changes its direction to backward. When the ball propels the body, the vector is inclined more than 10 degrees. The direction projected on the transverse elevation (frontal plane) changes only a little, within 5 degrees from the vertical line. The magnitude of vertical component is much greater than those of sagittal and transverse. Therefore the magnitude of vectors in these two planes is not much differed from that of the vertical force. The

Fig. 6 The changes of three components, the shifts of their point of action and postural changes. Subject: Y.F., Right foot, Velocity : $91 \mathrm{~cm} / \mathrm{sec}$.

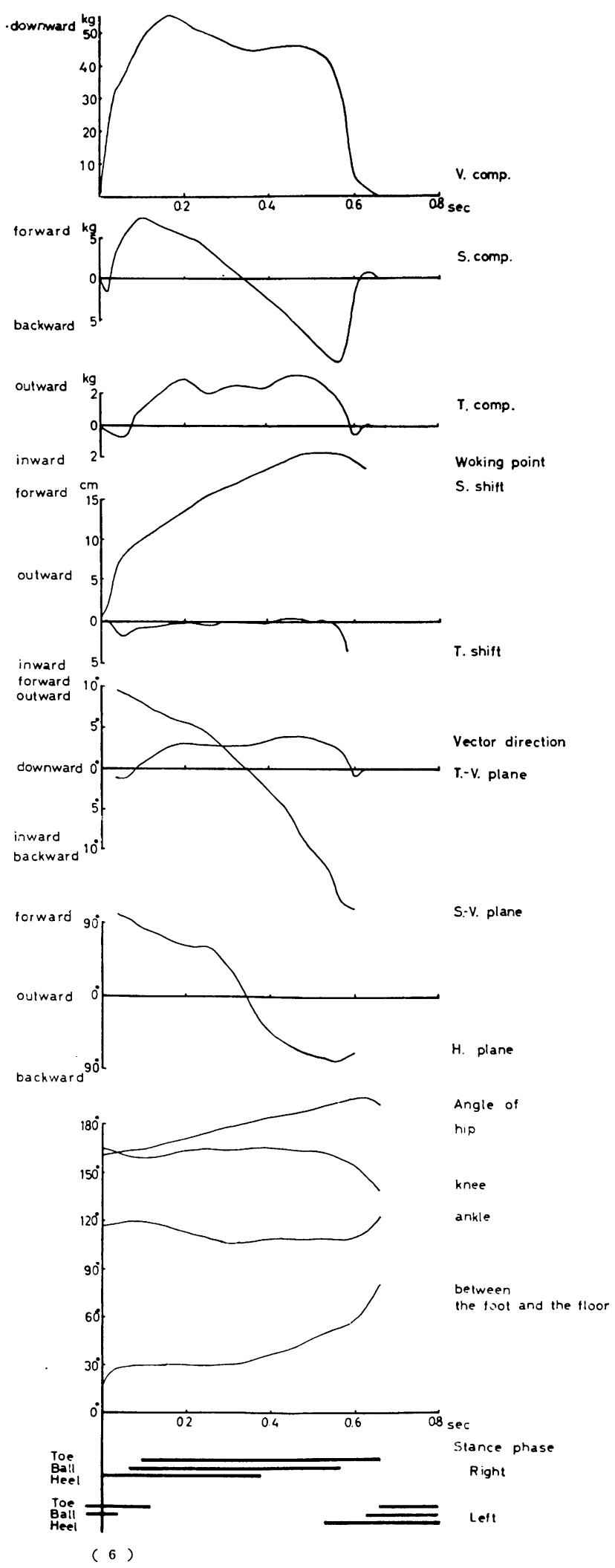




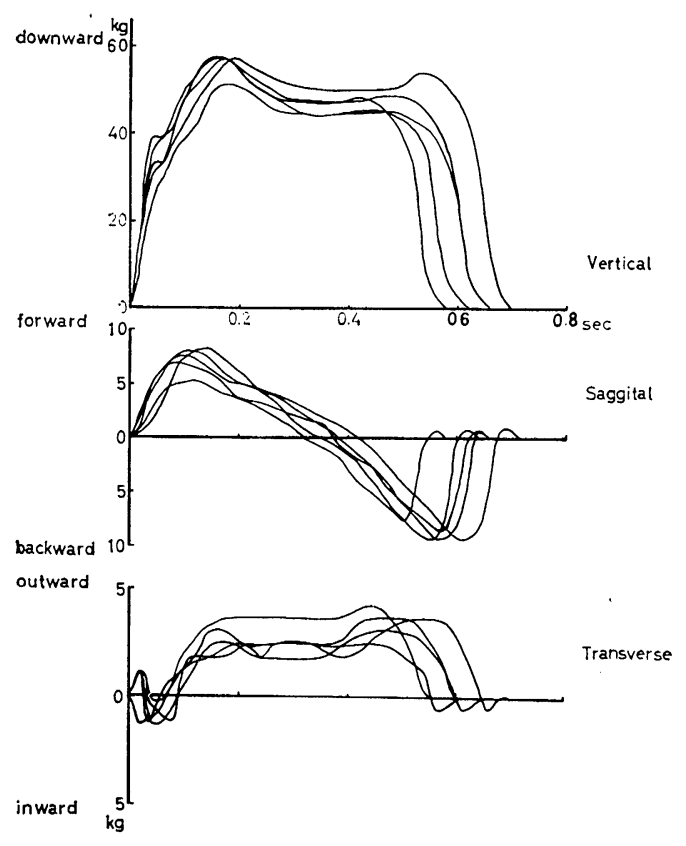

Fig. 7 Three components. Five trials of the same subject, Y.F. Right foot, Natural speed.

vector projected on the horizontal plane, points at first anteriorly and a little medially. It turns a bit laterally and stays there for a while, until it increases its magnitude rapidly. Then it turns quickly to lateral, decreasing the magnitude. It continues to turn posteriorly, increasing the magnitude again, until it points posteriorly.

The point of application A coordinates system with the sagittal ordinate and the transverse abscissa is used in order to indicate the location of the point of force application on floor. In the sagittal direction, after the heel becomes to be in close contact with the floor, the point of application moves forward rather straight. When it reaches around the ball, it stays there for a while. In the transverse direction, it shifts at first to the medial side, then it changes gradually to the lateral side and stays there. Just before the sole leaves the floor, the point shifts again to the medial side in some cases.

The changes of the foot force i. e., the resultant of the above components, in the stance phase are as follows. Soon after the heel strikes the floor, the force directs medio-infero-anteriorly (or medio-infero-posteriorly sometimes). Then the force shows a notch of its magnitude. As the ball gets in touch with the floor and the point of application moves forward, the force directs latero-infero-anteriorly. The forward component becomes the maximum around the time when the ball become in contact with the floor and another foot is leaving from the floor. Along this time, the downward component is growing large and it makes the maximum value after all parts of the sole touches the floor. Then the lower leg moves forward, the ankle is dorsiflexed and the point of application moves forward. Along with this movement the force becomes small, and directs almost inferiorly with a little lateral inclination. Then the heel begins to leave the floor. After this, the plantar flexion of the ankle begins and the point of application stays around the ball. The force directs postero-inferiorly and there appears the second peak of its magnitude. Then the 
knee flexes strongly and the heel of the another foot touches the floor. Now the backward kick makes the maximum value of the force and by this motion the body is propelled strongly. Then the posteroinferiorly force diminishes rapidly. The knee and the ankle are flexed markedly and the foot is off. Before the toe-off the transverse force component occasionally directs inward.

\section{DISCUSSION}

As seen in the diagram of the sagittal component, the numerical values of areas formed by the curve above and below the axis of abscissae are almost equal. It means that the speed of the body is constantly maintained during walking. It can be concluded that only in the last stage of the stance phase, when the large force is inclined backward, the body is pushed to make the forward locomotion as Goтон (1959) has declared. Rydell (1966) and IwAI et al. (1967) observed a small backward component of force just after the heel-strike. This backward component is also observed in some of our cases. Whether or not this backward component appears is dependant on the way how the heel touches the floor.

When a foot supports the body, the transverse component has the outward sense. This phenomenon is thought to be natural, because the center of gravity of the body is situated medial

Fig. 8 Three components. Ten subjects, upper five are males, lower five are females. Right foot, Natural speed.

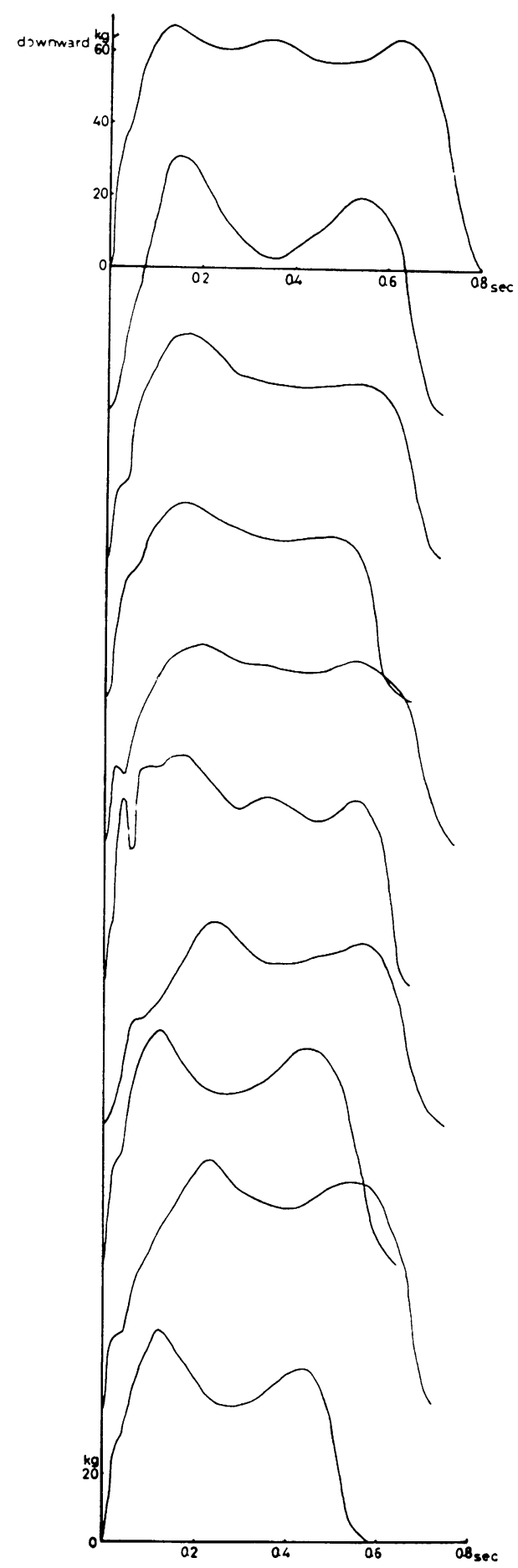

A) Vertical. 
Principal Pattern of the Dynamic Change in the Force of Human Foot during Walking 9

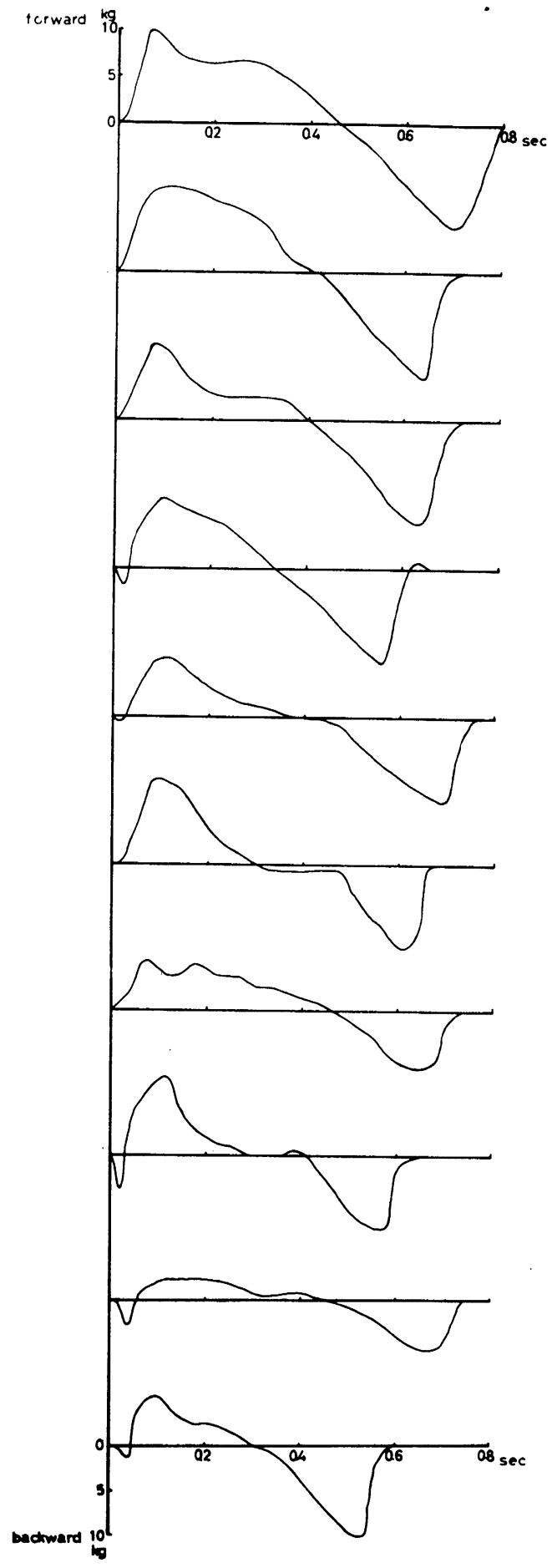

B) Sagittal.

inward

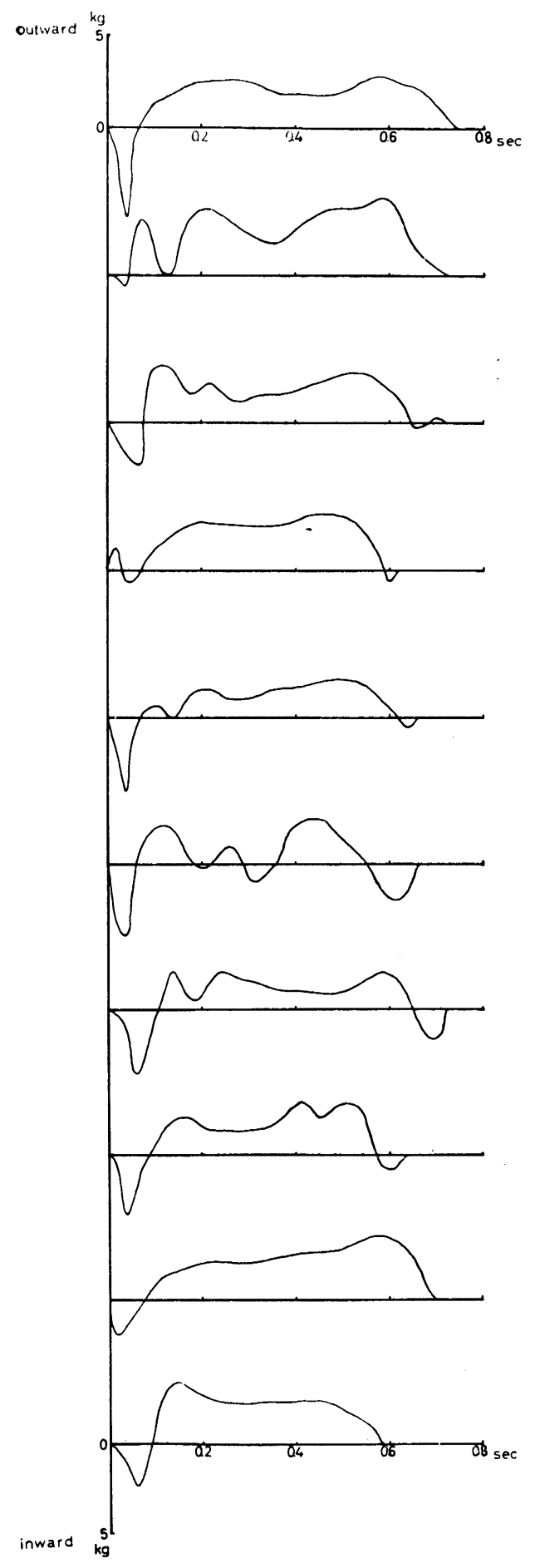

C) Transverse. 
to the foot.

In most of cases in this study, the first peak of vertical component is higher than the second one. Elftman (1939) and Gotoh (1959) showed that the second peak was higher. HAYASHIBARA et al. (1965) and IWAI et al. (1967) stated it depended on the cadence. Gотон (1959) did not observe the notch which appeared soon after the heel comes in contact with the floor. The reason might be that his analysing apparatus could not follow the detailed movement. As IWAI et al. (1967) mentioned, it could be the effect of heel percussion to the floor. The first inward peak of trasverse component appears at the same time. This would be also due to the same cause as they asserted.

The vector projected on the transverse elevation moves only a little and directs almost vertical as the body of the subject sways little to make an effective locomotion. In parallel with the sagittal elevation, the inclination of the vector is always small. But it becomes the maximum in the last stage when the foot powerfully kicks the floor backward. The reason may be that the body has to be constantly supported during locomotion.

As KoIWAI (1961) and other investigators have said, the ball of the foot touches the floor soon after the heel strikes the floor and the heel leaves at a time about the half of the stance phase. It is natural that the point of application moves forward rapidly after the heel-strike and then stays around the ball.

It could be said that the walk is a progression of an individual who is always supporting his body. The body is almost always supported vertically on the floor. The most powerful progression is made by the kick in the last stage. At that moment the another foot is going to touch the floor to support the body.

The acceleration, the velocity and the displacement of the body center of gravity were calculated by some authors. ConTini et al. (1965) took linear acceleration of the trunk at a point as close as possible to the body center of gravity by means of the accelerometer. They also recorded the forward velocity of the trunk at approximately the level of the body center of gravity by means of the tachograph. Though it is impossible to record the true body center of gravity, their technique will be one of the most direct method to record it. CAVAGNA et al. (1964) also studied the acceleration of the body center of gravity by means of the accelerometer. FISCHER (1899) took the photograph of the body movement in walking and calculated the movement of the body center of gravity from his observation. Then the derivative of the displacement was calculated to show the velocity and the acceleration. CAvAGNA and MARGARIA (1966) recorded the vertical and sagittal component to the floor 
Principal Pattern of the Dynamic Change in the Force of Human Foot during Walking 11 and calculated the acceleration in various kinds of walking speed. We tried to calculate acceleration, velocities and displacements of the approximate body center of gravity simultaneously from three components.

In this study we could not observe the forces of right and left foot simultaneously. But there is no significant difference between the force of right foot and that of left foot observed separately as seen in Fig. 4. Provided that the forces of the both sides are nearly equal, a series of addition was made as to the total force of the both sides along the sequence of time for the purpose to estimate the full forces acting on the body center of gravity. The result of the calculation in an exemplary case is seen in Fig. 9. The force divided by the weight of the body equals the acceleration. Acceleration thus calculated in three directions are illustrated also in Fig. 9. The integral of the acceleration equals the velocity. Such velocities in three dimensions are shown in Fig. 10. The displacement of the body center of gravity, which is the integral of the velocity, is illustrated in Fig. 11.

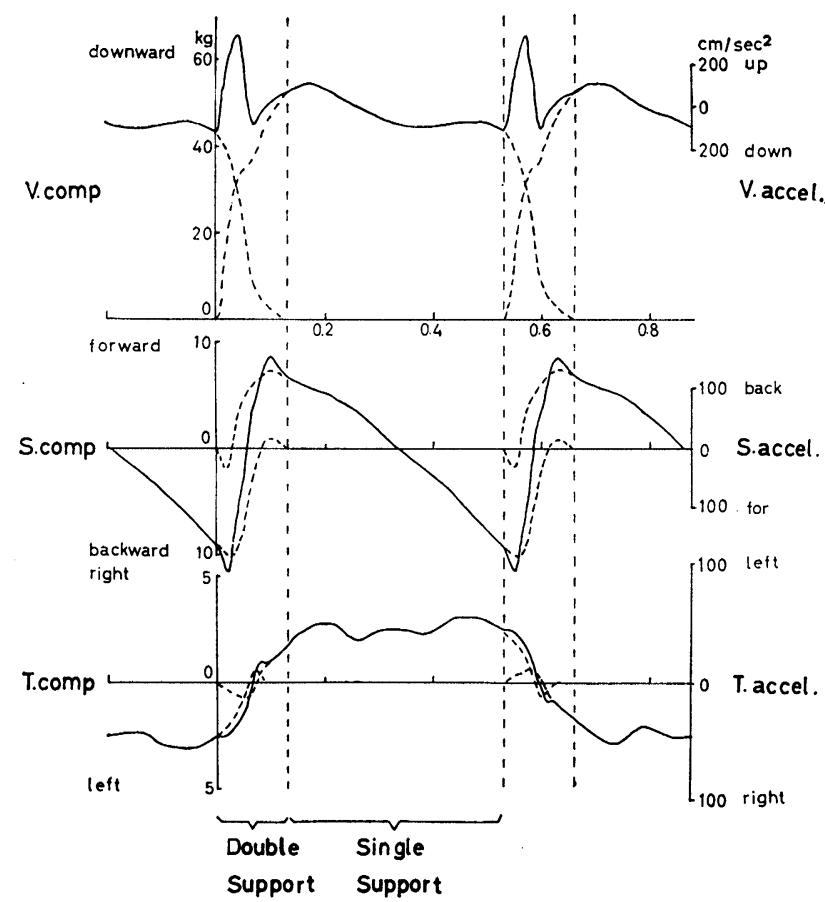

Fig. 9 Accelerations of the body center of gravity in three directions.

The same trial as Fig. 6.
The acceleration in the vertical direction has a high upward peak value around the double support phase. A wide downward acceleration of small magnitude appears in the middle of the single support phase. There is a forward peak and a backward peak value around the double support phase in the sagittal acceleration curve. The sense of the acceleration changes rapidly between them. The large forward acceleration caused by the foot in the rear may be soon stopped and changed in to backward acceleration by the foot in the front. The sense of the transverse acceleration changes

reversely in the double support phase. In single support phase, the magnitude of the component of the medial sense shows no large variation. The patterns of the vertical and the sagittal directional accelerations are not largely differed 
from those CAVAGNA and MARGARIA (1966) showed.

The vertical velocity curve has a deep downward trough around the double support phase. There appears the upward velocity in the single support phase. The sagittal velocity curve has a high forward peak in the middle of the double support phase. The magnitude of this peak is about $15 \mathrm{~cm} / \mathrm{sec}$ when measured from the level of the average speed. In the middle of the single support phase, there is a smooth trough. Its maximum value measured from the level of the average speed is about $10 \mathrm{~cm} / \mathrm{sec}$. The transverse velocity of the right sense has a

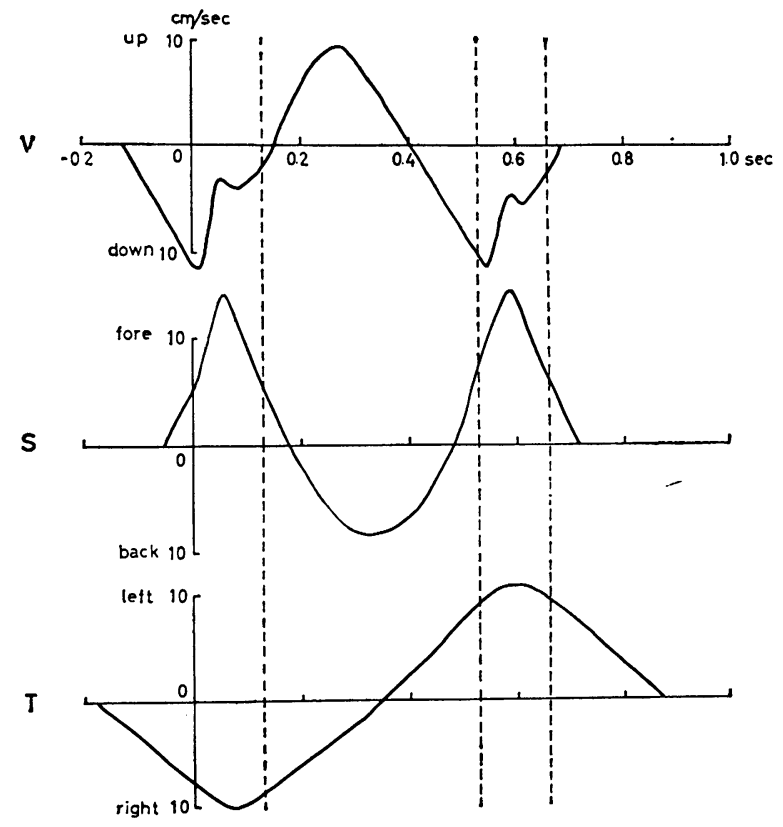

Fig. 10 Velocities of the body center of gravity in three directions. maximum value in the double support phase after the right heel-strike. The sense of the velocity changes gradually to the left in the right single support phase. The maximum value of the left appears after the left heel-strike. Both the maximum values are about $10 \mathrm{~cm} / \mathrm{sec}$.
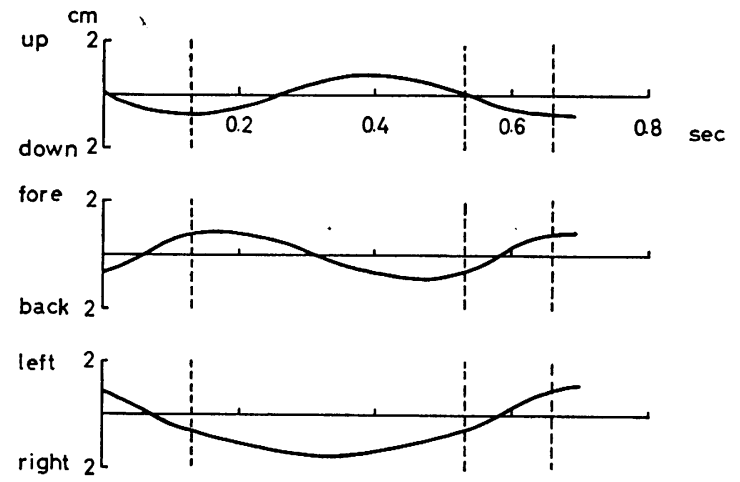

\section{Displacement}

Fig. 11 Displacements of the body center of gravity in three directions.
The displacement curve of the body center of gravity in three directions oscillates only a little. The right maximum is in the middle of the right stance. The forward maximum displacement from the level of the average is situated in the beginning of the single support phase and the backward maximum in the end of the same phase. The maximum value is about $1 \mathrm{~cm}$ in all. Fischer (1899) calculated the velocity and the acceleration from the discement of the cal- 
Principal Pattern of the Dynamic Change in the Force of Human Foot during Walking 13 culated body center of gravity. His patterns are almost the same with those of ours except in vertical direction. It can be concluded that the force exerted to the floor is caused by the body action which moves the center of gravity. The right directional force in the right foot stance phase is caused by the right directional movement of the center of gravity.

\section{SUMMARY}

The dynamic force exerted by the foot to the level floor in walking was analysed in the present study. A special dynamometer was devised for the purpose. Ten subjects were examined during several kinds of walking. Changes in the sagittal, transverse and vertical components of the foot force and the shift of its point of application during the stance phase are recorded along with the postural change of the subject taken with the $16 \mathrm{~mm}$ cine-camera.

From the results of the observation of the changing process of the force, it can be said that the human walk is a progression of the whole body which must be supported against the floor. The large force observed in early stage of the stance phase may be rather a supporting action of the body mainly by means of the heel; the large force observed in later stage may mean rather propulsive action by means of the ball and toe. Any way the body is always supported almost upright and sways little.

We express our appreciation to Prof. Yoshiyasu NAKAO of the Somatofunctional Laboratory, Faculty of Fine Arts, Tokyo University of Arts, for his help to this experiment. We also wish to express our thanks to Mr. Shunsaku Mitsuhashi of the Department of Mechanical Engineering, Faculty of Engineering, University of Tokyo, for his kindness providing facilities for the experiment.

\section{REFERENCES}

Cavagna, G. A., F. P. SAibane and R. MARgaria, 1964: External work in walking. J. Appl. Physiol., $18: 1-9$.

Cavagna, G. A., and R. Margaria, 1966: Mechanics of walking. J. Appl. Physiol., $21: 271$ -278 .

Contini, Renato, Howard GAGE and Rudolf Drillis, 1965: Human gait characteristics. Biomechanics and Related Bio-engineering Topics, Ed. R. M. KENEDI, pp. 413-429, Oxford.

Elftman, H., 1939: The force exerted by the ground in walking. Arbeitsphysiol., $10: 485$ $-491$.

Fischer, Otto, 1899: Der Gang des Menschen. II Theil, No. I, Tafel III-VI. Leipzig. Gотон, Takeshi, 1959: The dynamic studies on human gait. J. Jap. Orthop. Surg. Soci. 33 : 775-792. (Japanese with English abstract)

Hayashibara, A., T. Kosugi, M. Miyoshi, M. Saito and K. Kunisato, 1965: Hoko $n i$ okeru ashi-undo no bunseki. (An analysis of the movement of the leg in walking.) J. Jap. Orthop. Surg. Ass. $39: 666$. (Japanese)

IWAI, K., K. KozUmi, S. IINo, S. Seto and N. KimURA, 1967: Hoyō to yuka-hanryoku no 
dōkikiroku ni yoru seijōseijin hokō no undōrikigakuteki kenkyū. (Kinetic studies on the locomotion of normal human adult.) J. Jap. Orthop. Ass. 41 : 601. (Japanese)

KoIWAI, Itsuo, 1961: Basogram of walking with various pace times and running in adult. J. Jap. Orthop. Surg. Ass., $35: 1-42$. (Japanese with English abstract)

RAUHUT, Heinz, 1937: Über die bei der menschlichen Vorwärtsbewegung und bei ver. schiedenen Berufsarbeiten auftretenden Schubkräfte. Arbeitsphysiol. $9:$ 438-453.

RYDELL, Nils W., 1966: Forces acting on the femoral head-prosthesis. A study on strain gauge supplied prostheses in living persons. pp. 62-73, Göteborg.

SAUNDERS, M., V.T. INMAN and H.D. EBERHARDT, 1953: The major determinants in normal and pathological gait. J. Bone and Joint Surg. 35-A : 543-558.

SCHENK, H., 1937: Über die bei der menschlichen Fortbewegung auftretenden Lotkraft. Arbeitsphysiol. $9: 489-495$.

1) Department of Anthropology, Faculty of Science, University of Tokyo

2) Department of Anatomy, Faculty of Medicine, University of Tokyo

ヒトの歩行における足の力の主な動的変化

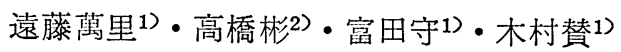

二足歩行はヒトの重要な特徵と考えられており, 種々の研究が行われてきている。しかしながら歩行の 際に足が床に及ぼす力の動力学的解析は多くはない。乙の力を前後, 左右, 上下の三分力に分解し, 同時 記録した研究としては ELFTMAN (1939), 後藤（1959）などがおむなあのとしてあげられる。我々は歩 行の際のヒトの歩行器官の力学的特性を解明するととを目的として, 足より水平な床に及ぼされる力の基 本的変化を観察した。

力を動的に测定するため，電気抵抗線霜計を用いた特別な力量計を設計した（Fig. 1,2)。被験者は裸 足で助歩路を数歩歩いた後, この力量計を踏む (Fig. 3)。同時に $16 \mathrm{~mm}$ 映画の撮影を行い, 姿勢の分 析を行つた。速歩, 普歩, 遅歩の三種の歩速における記録をとつた。被験者は 5 人の男子, 5 人の女子, 計 10 人の正常成人である。

歩行速度, 足の左右が変つても, 力の基本的変化汇関してはほぼ変りがないと見ら机る (Fig. 4,5)。普 通の速度における右足の力の変化がFig. 7,8 に示されている。Fig. 6 は姿勢変化, 力の大きさの変化, 力の作用点の変化を一例について同時的俵わしたものである。前後方向分力は接地後まず前方への, す なわち制動するような向きに生じ，急速に大きくなつて最大值を示し，次に徐々に減つて，接地時のほぼ 中央で向きを後方へ変える。後方への成分の值は徐々に大きくなり, 最大值をなした後, 急に小さくなつ て0となる。最大值の値は, 普通速度では, 後方へ向くあのが前方へ向くものよりやや大きい。左右方向 分力は着地直後では问きを内方にとるが，すぐ外方へかわり，そのまま一定となる。しかし離地直前にま た内方に向くことがある。下方への分力の曲線は着地後一度段をなしてから最大值をつくり，その後いっ たん小さくなるが，再び大きく山をつくる。

カのベクトルの向きは前下方より外下方, 後下方へとまわる。ベクトルが鉛直線となす角度は, 前方へ は着地直後に約 $10^{\circ}$, 側方へは最大值 $5^{\circ}$ 程度, 後方へは離地直前に $10^{\circ}$ 以上となる。力の作用点は着地後 踵附近にしばらくとどまつた後，かなり一直線に前方へ進み，趾球附近でまたしばらくとどまる。

身体の運動が剛体の運動に近似するとして 。この実験からえられた三次元の力の変化から, 体重心の加 速度, 速度, 変位の变化を計算してみた。乙れらの三次元の值を三方向に分解して㳖わした一例が Fig. 9,10,11 亿示されている。乙の結果は基本的には他の方法による結果と大差ない。

歩行の際，ヒトの体は前進しながらも常に支えられていると理解するてとができる。また，体は左右に は少ししかゆ机ず，垂直に近い力で支持さ机ている。

(1) 東京大学理学部人類学教室 ${ }^{2)}$ 東京大学医学部解剖学教室) 